\title{
PRESTASI BELAJAR MATEMATIKA MATERI BILANGAN BERPANGKAT DENGAN PENERAPAN MODEL PEMBELAJARAN TIPE STAD MELALUI MEDIA INFOCUS PADA SISWA MTs TERPADU KOTA LANGSA
}

\author{
Azizah $^{1}$ \\ ${ }^{1}$ Madrasah Tsanawiyah Terpadu, Jalan Islamic Center, Langsa 24414, Indonesia \\ Email: azizah.lgs@gmail.com
}

\begin{abstract}
Abstrak
Tujuan dalam penulisan ini untuk mengetahui prestasi belajar dengan penerapan model pembelajaran type STAD melalui media infocus dalam peningkatan hasil belajar matematika materi bilangan berpangkat bagi di siswa MTS Terpadu Kota Langsa. Metodologi dalam penulisan ini menggunakan metode penelitian tindakan kelas (action research room) dengan hasil penelitian dilakukan dalam memecahkan masalah pembelajaran di kelas melalui perencanaan, tindakan, pengamatan dan refleksi. Hasil penulisan menunjukkan bahwa aktivitas guru dan siswa telah mencerminkan penerapan model pembelajaran type STAD dengan media infocus. Mengukur keberhasilan dalam tindakan kelas adalah sistem belajar tuntas yaitu setiap siswa telah mencapai nilai 70 maka dikatakan berhasil tuntas. Secara klasikal, apabila mencapai 80\% siswa telah mencapai nilai 70 maka dikatakan tuntas secara klasikal. Nilai rata-rata yang diperoleh sebesar 78.24 dengan jumlah siswa tuntas 32 orang dan tidak tuntas 2 orang. Dalam persentase tuntas klasikal sebesar 94\%, hasil ini telah melebihi indikator ketuntasan yang ditetapkan.
\end{abstract}

Kata kunci: Pembelajaran, Matematika, Tipe STAD, Infocus

\section{Abstract}

The purpose of this paper is to determine learning achievement by applying STAD type learning models through infocus media in improving mathematics learning outcomes for rank numbers material for Integrated MTS students in Langsa City. The methodology in this writing uses a classroom action research method with the results of research conducted in solving learning problems in class through planning, action, observation and reflection. The writing results show that the teacher and student activities have reflected the application of the STAD type learning model with infocus media. Measuring success in classroom action is a complete learning system in which each student has reached a value of 70 then it is said to be successful. Classically, if $80 \%$ of students have reached 70, they are said to be classically complete. The average value obtained was 78.24 with the number of students completing 32 people and not completing 2 people. In the classical completion rate of $94 \%$, this result has exceeded the established completeness indicator.

Keywords: Learning, Mathematics, Stand Type, Infocus

\section{PENDAHULUAN}

Matematika adalah mata pelajaran yang diajarkan mulai dari tingkat Sekolah Dasar (SD) sampai Sekolah Tingkat Menengah (SMA). Sampai saat ini matematika masih dianggap mata pelajaran yang sulit, membosankan, bahkan menakutkan. Anggapan ini mungkin tidak berlebihan selain mempunyai sifat yang abstrak, pemahaman konsep matematika yang baik sangatlah penting karena untuk memahami konsep yang baru diperlukan pemahaman konsep sebelumnya. 
Tahap Simbolik sebagaimana dijelaskan oleh Hidayat (2004:9) adalah suatu tahapan pembelajaran dimana pengetahuan itu direpresentasikan dalam bentuk simbol-simbol abstrak, baik simbol-simbol verbal (misalnya huruf-huruf, kata-kata atau kalimat-kalimat), lambang-lambang matematika maupun lambang-lambang abstrak lainnya. Menurut Wahab Jufri (2013: 81), belajar merupakan aktivitas peserta didik untuk menguasai kompetensi sesuai dengan tujuan yang diharapkan. Oleh karena itu strategi pembelajaran harus dapat mendorong peserta didik untuk aktif secara fisik dan mental. Aktivitas belajar diwujudkan dalam bentuk rumusan pengalaman belajar peserta didik yang difasilitasi oleh pendidik.

Dalam konteks dunia pendidikan, sebagaimana Gerlach \& Ely yang dikutip oleh Arsyad (2002: 3) mengungkapkan bahwa media secara garis besar adalah manusia, materi, atau kejadian yang membangun kondisi yang membuat siswa mampu memperoleh pengetahuan, keterampilan, atau sikap. Dalam pengertian ini, guru, buku teks, dan lingkungan Sekolah merupakan media. Secara lebih khusus, pengertian media dalam proses pembelajaran cenderung diartikan sebagai alat-alat grafis, photografis, atau elektronis untuk menangkap, memproses, dan menyusun kembali informasi visual atau verbal.

Pengalaman penulis, selama mengajar di kelas IX-A MTs Terpadu Kota Langsa banyak kendala yang ditemui diantaranya banyak ditemukan kesulitan-kesulitan yang dialami siswa di dalam mempelajari matematika. Salah satu kesulitan itu adalah tidak mampu memahami konsep pada materi Bangun ruang sisi lengkung. Akibatnya terjadi banyak kesulitan siswa dalam menjawab soal-soal baik soal-soal ulangan yang berhubungan dengan bangun ruang sisi lengkung. Selama ini media pembelajaran yang dipakai adalah alat peraga yang terbuat dari tripleks-tripleks. Tetapi seiring dengan berkembangnya teknologi, media pembelajaran tersebut kurang menarik perhatian dan minat siswa.

Perlu dikembangkan suatu tindakan berupa suatu penigkatan prestasi belajar matematika siswa berupa penerapan pembelajaran type STAD dengan media infocus untuk memberikan kesempatan kepada siswa dalam mengemukakan gagasan-gagasan terhadap pemecahan suatu masalah dalam kelompoknya masing-masing. Pemilihan media pembelajaran dengan menggunakan media infocus dikarenakan akhir-akhir ini di lingkungan akademis atau pendidikan penggunaan media pembelajaran yang berbentuk media infocus dapat lebih menarik perhatian dan minat siswa tanpa mengurangi fungsi media pembelajaran secara umum.

\section{METODE PENELITIAN}

Jenis penelitian ini adalah penelitian tindakan kelas (Classroom Action Research). Tujuannya adalah untuk memperbaiki atau mengubah situasi pembelajaran operasi bilangan bulat, yang dipandang bermasalah. Pemilihan metode ini didasarkan bahwa penelitian tindakan kelas bertujuan untuk mencari prosedur baru untuk memperbaiki dan meningkatkan professional guru dalam proses pengajaran di kelas dengan melihat berbagai indikator keberhasilan proses dan hasil pengajaran yang terjadi pada siswa (Hopkin, 1993: 32-33, Suyanto, 1997 : 2).

Penelitian diharapkan dapat meningkatkan daya serap siswa yang optimal maka dimungkinkan adanya tindakan yang berulang-berulang dengan revisi rancangan dan pelaksanaan untuk meningkatkan hasil dan efektivitas suatu rancangan dan disain pembelajaran yang dilaksanakan guru dan peneliti berperan aktif dari tahap perencanaan sampai pada evaluasi dan refleksi hasil tindakan.

\section{HASIL PENELITIAN DAN PEMBAHASAN}

Pembahasan tiap siklus dan antar siklus akan dijelaskan hasil pelaksanaan tiap siklus dan perbandingan hasil belajar antar siklus

1. Pembahasan siklus. 
a. Hasil Siklus I. Pada siklus 1 berdasarkan data di atas ditemukan bahwa dari segi rangkuman materi terlihat hasil yang belum memuaskan terutama pada isi dan sistematika rangkuman. Sedangkan cara mempresentasikan beberapa kelompok masih terlihat kurang lancar dan sistematika pengungkapan juga masih perlu di perbaiki. Keterlibatan siswa anggota kelompok sudah cukup memuaskan terutama saat menjelang presentasi. Karena peneliti merasa hasil yang didapat pada siklus 1 masih kurang memuaskan maka peneliti mengadakan kegiatan siklus berikutnya. Perolehan hasil belajar dengan analisis hasil tes formatif 1 memperoleh ketuntasan belajar mencapai 59\% atau 20 siswa yang tuntas belajar belum mencapai target $\geq 80 \%$ ketutasan klasikal dari kondisi awal yang hanya 14 orang atau $41 \%$ yang tuntas belajar pada materi bilangan berpangkat.

b. Hasil Siklus II. Pada siklus II pertemuan pertama dan kedua terjadi peningkatan yang cukup berarti. Isi dan sistematika rangkuman sudah semakin baik sehingga secara keseluruhan rangkuman materi setiap kelompok baik. Hal ini terjadi karena telah dilakukan peningkatan bimbingan terhadap siswa tentang cara menyusun rangkuman yang baik. Cara Mempresentasikan berdasarkan tontonan media infocus rangkuman materi juga mengalami peningkatan terutama dari segi kelancaran. Tampaknya siswa mulai terbiasa untuk mempresentasikan pengetahuan yang dikuasainya. Keterlibatan siswa terlihat lebih terkoordinasi dan hasil yang dicapai juga meningkat. Perolehan hasil belajar pada siklus II dengan hasil analisis tes formatif 2 menunjukan siswa yang tuntas belajar sudah mencapai target walau ada 1 orang siswa yang belum tuntas namun secara klasikal sudah mencapai terget penelitian yaitu tingkat ketuntasan mencapai $94 \%$ atau 32 orang siswa yang tuntas dari 34 orang dalam satu kelas sedangkan yang belum tuntas hanya $6 \%$.

2. Pembahasan Antar Siklus

Dari antar siklus tindakan kelas pelajaran matematika materi bilangan berpangkat, merefleksikan ternyata memang benar bahwa belajar aktif dengan metode STAD dengan penggunaan media infocus dapat meningkatkan hasil belajar siswa. Hal dengan menunjukkan peningkatan hasil belajar atau ketuntasan belajar antar siklus adalah siklus I ketuntasan kalsikal 59\% meningkat dari pra siklus yang hanya $41 \%$. Sedangkan pada siklus II naik signifikan yang mencapai $94 \%$ meningkat $35 \%$ dari siklus I, sehingga nilai rata-rata antar siklus juga meningkat dari pra siklus 56.18 naik pada siklus I 66.76 dan pada siklus II 78.24.

\section{Gambar 1.}

\section{Diagram Perbandingan Hasil Belajar Antar Siklus}

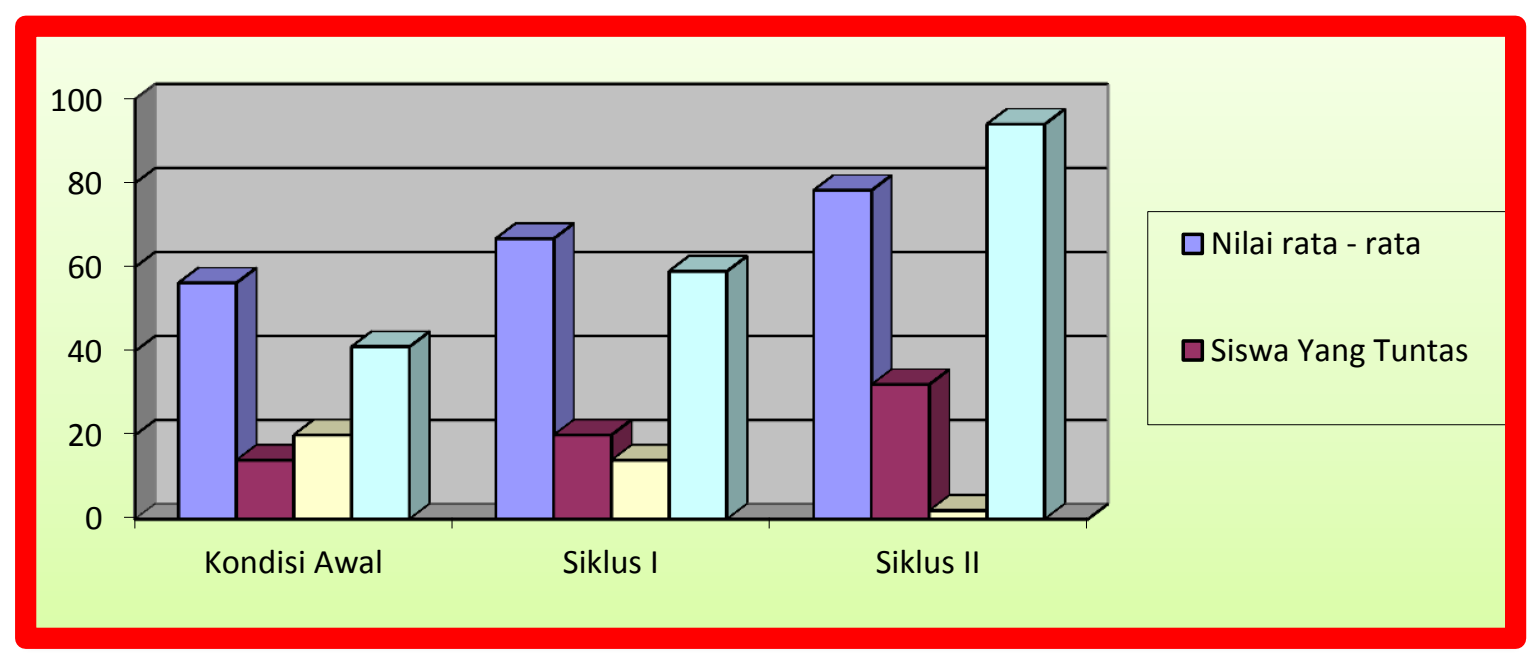


Berdasarkan gambar diagram diatas menunjukan ketuntasan belajar yang ditunjukkan oleh batang berwarna hijau muda ketuntasa klasikal meningkat antar siklus. Dari siklus I memperoleh hasil belajar dengan analisis hasil tes formatif 1 dengan memperoleh ketuntasan belajar mencapai $59 \%$ atau 20 siswa yang tuntas belajar belum mencapai target $\geq 80 \%$ ketutasan klasikal dari kondisi awal yang hanya 14 orang atau $41 \%$ yang tuntas belajar pada materi bilangan berpangkat. Sedangkan siklus II, setiap siswa mulai terbiasa untuk mempresentasikan pengetahuan yang dikuasainya. Keterlibatan siswa terlihat lebih terkoordinasi dan hasil yang dicapai juga meningkat. Perolehan hasil belajar pada siklus II dengan hasil analisis tes formatif 2 menunjukan siswa yang tuntas belajar sudah mencapai target walau ada 1 orang siswa yang belum tuntas namun secara klasikal sudah mencapai terget penelitian yaitu tingkat ketuntasan mencapai $94 \%$ atau 32 orang siswa yang tuntas dari 34 orang dalam satu kelas sedangkan yang belum tuntas hanya $6 \%$.

\section{KESIMPULAN}

Setelah melakukan perbaikan pembelajaran, telah diperoleh kemajuan yang sangat baik pada mata pelajaran matematika materi bilangan berpangkat yang diberikan. Hasil yang didapat pada siklus I dan jumlah siswa yang mendapat nilai 70 kebawah berjumlah 20 orang dan masih ada kelompok yang belum maksimal hasil rangkuman materinya dan cara mempresentasikan masih kurang lancar, dengan diberikan bimbingan cara merangkum, mempresentasikan hasil rangkuman dan mencari materi yang esensial terjadi peningkatan cara peserta didik mempresentasikan hasil rangkumannya. Hasil evaluasi akhir yang dilaksanakan secara individu melampaui target yang ditetapkan.

Perbaikan yang telah dirancang dan telah menunjukan keberhasilan yang baik bagi peserta didik dalam meningkatkan kinerja guru dan siswa. Dengan hasil belajar pada siklus II, siswa yang yang memperoleh nilai 70 kebawah hanya 2 orang itupun karena IQ yang berbeda dengan siswa lain. Ketuntasan hasil belajar siswa melalui hasil peneilitian ini menunjukkan bahwa metode STAD dengan menggunakan media infocus memiliki dampak positif dalam meningkatkan prestasi belajar siswa. Hal ini dapat dilihat dari semakin mantapnya pemahaman siswa terhadap materi yang di diskusikan melalui tontonan media infocus (ketuntasan belajar telah tercapai) yaitu 94\% ketuntasan belajar siswa secara klasikal telah tercapai pada akhir siklus II.

\section{REFERENCES}

A Wahab Jufri.(2013) Belajar dan Pembelajaran Sains, Bandung: Pustaka Reka Cipta

Azhar, A. (2002). Media Pembelajaran, Edisi 1, Jakarta: PT. Raja Grafindo.

Asma, N. (2006). Model Pembelajaran Kooperatif, Jakarta : Departemen, 20

Depdikbud. (1994). Kurikulum Pendidikan Dasar (GBPP), Jakarta: Depdikbud

Olihatin,E. (2005). Pengaruh Kooperatif Learning Terhadap Belajar IPS Tinjau. Dari Gaya Belajar, Jakarta : Bumi Aksara

Hidayat. (2004). Diktat Kuliah Teori Pembelajaran Matematika, Semarang: FMIPA UNNES.

Kemmis, S \& McTaggart. R. (1998). The Action Research Planner Third Edition, Victoria: Deakin University.

Moch. Masykur Ngabdul Halim. (2007). Matematical Intellegence, Jogjakarta: Ar-Ruzz Media. 
MGMP Matematika Kota Semarang. (2007). LKS Matematika SMP/ MTs, Semarang : CV. Jabbaar Setia.

Nana Sudjana. (1997). Media Pengajaran Bahasa, Yogyakarta: Intan Pariwara.

Sartono Wirodikromo. (2006). Matematika untuk SMP Kelas IX, Jakarta : Penerbit Erlangga.

Sutrisno. (2012). Kreatif Mengembangkan Aktivitas Pembelajaran Berbasis TIK, Jakarta: Referensi

SanjayaW. (2008). Perencanaan dan Desain Sistem Pembelajaran, Jakarta: Kencana Prenada Media Group.

Supriyono. (2008). Psikologi Belajar, Jakarta: PT Rineka.

Save M Dagun.(2006). Kamus Besar Ilmu Pengetahuan, Jakarta: Lembaga Pengkajian Budaya.

Tim Matematika SMP (2004). Matematika 1 Untuk SMP Kelas IX, Jakarta :PT. Galaxy Puspa Mega,

The Liang Gie. (2012). Pengantar Filsafat Ilmu, Yogyakarta: Liberty Yogyakarta. 
